\title{
Parasitic survey on introduced monk parakeets (Myiopsitta monachus) in Santiago, Chile
}

\author{
Levantamento parasitário da caturrita (Myiopsitta monachus) introduzida em Santiago, Chile \\ Cristóbal Briceño ${ }^{1}$; Dominique Surot ${ }^{1}$; Daniel González-Acuña ${ }^{2}$; Francisco Javier Martínez ${ }^{3}$; Fernando Fredes ${ }^{1 *}$ \\ ${ }^{1}$ Departamento de Medicina Preventiva Animal, Facultad de Ciencias Veterinarias y Pecuarias, Universidad de Chile, Santiago, Chile \\ ${ }^{2}$ Departamento de Ciencias Pecuarias, Facultad de Medicina Veterinaria, Universidad de Concepción, Chillán, Chile \\ ${ }^{3}$ Departamento de Sanidad Animal, Facultad de Veterinaria, Universidad de Córdoba, Córdoba, Spain
}

Received November 14, 2016

Accepted March 31, 2017

\begin{abstract}
Central Chile has been identified as a unique ecosystem with high conservation priority because of its high levels of endemism and intensive anthropic pressure. Over a period of almost four decades, the monk parakeet has been successful in establishing and dispersing in urban Santiago, although little is known about its potential impact. Furthermore, nothing is known about its epidemiological risks towards animals or even humans. For this reason, we conducted the first parasitic survey of monk parakeets in Chile through capture, necropsy and thorough external and internal inspection of 92 adult individuals. Among these, $45.7 \%$ presented lice that were identified as Paragoniocotes fulvofasciatum, 1.1\% had mesostigmatid acari and $8.9 \%$ had free-ranging acari. Among 89 parakeets, $19.1 \%$ had structures identified as Cryptosporidium sp. This study provides the first description of Cryptosporidium sp. in monk parakeets. Along with the presence of a mesostigmatid acarus in one parakeet, this serves as a public health warning, given that both of these parasites have zoonotic potential.
\end{abstract}

Keywords: Psittacidae, Paragoniocotes fulvofasciatum, mesostigmatid acarus, oribatid acari, Cryptosporidium.

\section{Resumo}

A porção central do Chile é reconhecidamente uma área com ecossistemas únicos de alta prioridade para conservação. Isso se deve aos altos níveis de endemismo na região e pressóes antrópicas intensas. Durante quase quatro décadas, a caturrita tem obtido sucesso em seu estabelecimento e dispersão na área urbana de Santiago, apesar da falta de conhecimento com relação ao seu potencial impacto. Além disso, não há informaçôes sobre riscos epidemiológicos para animais e tampouco para humanos. Motivado por essa questão, foi realizado o primeiro levantamento parasitário de caturritas no Chile a partir da captura, necropsia e inspeção interna e externa de 92 indivíduos adultos. Deste total, 45,7\% apresentaram piolhos da espécie Paragoniocotes fulvofasciatum, 1,1\% apresentaram ácaros da ordem Mesostigmata, e $8,9 \%$ apresentaram ácaros de vida livre. Dentre 89 caturritas, 19,1\% apresentaram estruturas identificadas como Cryptosporidium sp. Este estudo apresenta a primeira descrição de Cryptosporidium sp. em caturritas. Ademais, a presença de ácaros da ordem Mesostigmata em uma das aves serve como um alerta para saúde pública, considerando que estes dois parasitas apresentam potencial zoonótico.

Palavras-chave: Psittacidae, Paragoniocotesfulvofasciatum, ácaro mesostigmatídeo, ácaro orobatídeo, Cryptosporidium.

\section{Introduction}

The monk parakeet (Myiopsitta monachus) is a medium-sized sexually monomorphic parrot originally distributed in Paraguay, Uruguay, Bolivia, southern Brazil and northern and central Argentina (EBERHARD, 1998). As non-migrants, they remain in their nests both for nesting and for roosting year-round (NAVARRO et al.,

\footnotetext{
*Corresponding author: Fernando Fredes. Departamento de Medicina Preventiva Animal, Facultad de Ciencias Veterinarias y Pecuarias, Universidad de Chile, Av. Santa Rosa, 11.735, La Pintana, Santiago, Chile. e-mail: ffredes@uchile.cl
}

1995). It is the only parrot, among over 350 species, that is able to build its own communal nests, thus making them independent of the need for tree or cliff cavities (MARTIN \& BUCHER, 1993).

In Argentina, the monk parakeet's original range is increasing southwards towards southern Patagonia (BUCHER \& ARAMBURÚ, 2014) and, within its native range, it is currently considered to be a pest (ISSG, 2011). Consequently, it is estimated that in Argentina this invader causes $2-15 \%$ crop losses, with an annual cost of over US\$ 1 billion (IRIARTE et al., 2005). 
Currently, invasive populations of monk parakeets can be found worldwide as an unintentional by-product of large-scale pet trade (EDELAAR et al., 2015). In both native and invasive sites, the monk parakeet is considered to be a problem for agriculture and for electricity transmission lines (BUCHER \& ARAMBURÚ, 2014). In England, this species has been classified as one of the six priority invaders for rapid reaction (VAN HAM et al., 2013). In United States, parakeets build nests mostly on manmade structures being considered a nuisance by utility companies (BURGER \& GOCHFELD, 2009; AVERY et al., 2012; REED et al., 2014). In Florida, the species has thrived and has become urban and suburban without any observed limits to their population growth (AVERY et al., 2012). In Spain, most information on monk parakeets has been produced in Barcelona, where they are mainly concentrated in urban areas. This population is estimated to double every nine years and was found to be highly dependent on bird feed (DOMÈNECH et al., 2003; RODRÍGUEZ-PASTOR et al., 2012).

In Chile, there is little information about the invasion of monk parakeets. However, these birds are considered to be the newest and most troublesome invasive species. Monk parakeets are blamed for a major negative impact on fruit and ornamental trees. They were first released by private citizens in eastern Santiago in 1972 (IRIARTE et al., 2005). The Chilean official Agriculture and Livestock Bureau (Servicio Agrícola y Ganadero, SAG) has reported that the first naturalized colony was established during the early 1980s, in a radio antenna in La Reina commune, eastern Santiago. From there, the birds would have slowly colonized the landscape through dispersal to nearby areas (TALA et al., 2005). During the 1990s, sightings of parrot flocks became more frequent in the higher parts of La Reina and Lo Barnechea communes in Santiago. In total, it has been estimated that 15,000 individuals were imported from the time of their first introduction until the time when the species was declared harmful and its importation was banned through the Hunting Law (No. 19.473) in 1997 (IRIARTE et al., 2005; TALA et al., 2005). Through either intentional releases or escaping parrots, by 1998 parrots became common mainly in the eastern communes of the city of Santiago (specifically in Las Condes, La Reina and Nuñoa). Since then, the population has been increasing with parakeets spreading through central Chile further towards the south (La Pintana commune), the west (Maipú commune) and the north (Lampa commune) of Santiago (TALA et al., 2005), with breeding colonies reaching as far as the west coast in Valparaíso region (IRIARTE et al., 2005).

Biological invasions are closely linked to the emergence of diseases and have the potential to affect the health of people and domestic animals (KEESING et al., 2010; DUNN \& HATCHER, 2015), given that they are a source of spreading of zoonoses (ESTRADA-PEÑA et al., 2014) including parasites (THOMPSON, 2013). Ecological interactions of monk parakeets with other introduced birds, such as sparrows or pigeons, could pose a risk of transmission of zoonotic pathogens, especially to immunologically susceptible individuals such as young children, elderly people or sick individuals (HAAG-WACKERNAGEL \& MOCH, 2004; COSTA et al., 2010).

So far, no information on potential microorganisms that monk parakeets may be harboring is available in Chile. Central
Chile is one of the 25 unique biodiversity hotspots in the world, because of its high levels of endemism and intensive level of anthropic pressure (MYERS et al., 2000). Despite identification of this highly endemic and endangered biota, the threats to Chile's biodiversity may still have been underestimated (BROOKS et al., 2002). In addition, biological invasions and the emergence of diseases have the potential to contribute to wildlife extinctions, particularly when these invasions interact with other driving factors (DASZAK et al., 2000; HARVELL et al., 2002; SMITH et al., 2009). Furthermore, parasites have the potential to affect wildlife populations and have been identified as causative agents of population declines (THOMPSON, 2013).

So far in Chile, the monk parakeet invasion has been completely overlooked and, moreover, it appears that it is expanding to new urban areas, and even rural areas (TALA et al., 2005).

The objective of this study was to survey internal and external parasites in urban monk parakeets that were caught in central Chile.

\section{Materials and Methods}

Sampling of individuals was conducted at La Dehesa Golf Club (3320' S; 70³0' W), a private area located in the municipality of Lo Barnechea in the Andes foothills, on the eastern side of Santiago, Chile. Monk parakeets were hunted between August 2006 and April 2007, and were handled in accordance with the recommendations from the official body (Servicio Agrícola y Ganadero; SAG), under University's Ethics Committee authorization (No. 4042006). Dead parakeets were processed immediately, while injured parakeets were euthanized and were placed in closed containers filled with cotton wool that was saturated with chloroform (BLACKSHAW et al., 1988), after obtaining blood for smears. All inanimate birds were then inoculated intraperitonially using 10\% formalin, individually stored in sealed plastic bags, and transported inside a cooler to the Parasitological Laboratory of the School of Animal and Veterinary Sciences, University of Chile.

In the laboratory, exhaustive inspection was conducted in order to observe and isolate ectoparasites. Additionally, feathers were combed thoroughly and loose feathers and scales that were left in the plastic bags were inspected. All ectoparasites found were placed in vials with $70 \%$ ethanol and labeled according to their origin.

The ectoparasites were soaked in $20 \% \mathrm{KOH}$ (day one, $24 \mathrm{~h}$ ) to clean them and remove debris, and were then left in distilled water for $24 \mathrm{~h}$ (day 2). During day 3, the parasites were immersed in ascending ethanol concentrations (40\%, 70\% and 96\%) for five to ten minutes in each of these, and were finally deposited in poppy seed oil to be cleared for $24 \mathrm{~h}$. On the fourth day, the ectoparasites were mounted in Canada balsam to be observed under a bifocal magnifier (PALMA, 1978). Identification of ectoparasites was conducted following Price et al. (2003), whereas species was determined following Guimarães (1947) and Palma (1973) for Paragoniocotes fulvofasciatum, in particular.

Among all the birds collected, complete necropsies were performed on most of them. Sex was determined through visual examination of the gonads, and organs were examined exhaustively for endoparasites. Five complementary methods for parasite detection were applied: 
a) Direct examination of four sections of the digestive tract: Esophagus and crop; stomachs; small intestine; and large intestine. All sections were tied up separately and each organ was opened with scissors and individually washed to place all its content on a white tray for observation. After the particles had been separated according to fragment size, drops of Lugol's iodine were applied and left to act for one minute (the excess was then washed off), to aid visualization of internal parasites.

b) Flotation method on the contents of each of the four tied-up sections was applied and observation performed under a microscope with 10X and 40X objective lenses (SOULSBY, 1987).

c) Sedimentation method on the same remaining subset of samples was applied and sediment was observed under a bifocal magnifier (SOULSBY, 1987).

d)Ziehl-Neelsen technique (adapted from FAYER \& XIAO, 2008) was applied to smears from feces and from digestive content collected with stick swabs from each of the digestive segments that were observed on the trays. The smears, once dry, were covered with basic fuchsine, heated enable to vapor emission and stained for 20 minutes. Subsequently the slides were washed with tap water. Acid alcohol was then added for 30 seconds and rinsed with tap water. The slides were then covered with methylene blue for two to five minutes and rinsed in tap water. Finally, the smears were air-dried and observed under an optical microscope using a 100X objective lens.

e) Hemoparasites were also surveyed using blood smears produced in the field. In the laboratory, these smears were stained using Giemsa.

The results from these analyses were recorded and the frequency of parasites found was established, along with the intensity of infection and abundance, based upon definitions given by Bush et al. (1997). Additionally, the frequencies were compared using a chi-squared analysis, to explore sex-related differences and also any possible association between ectoparasites and endoparasites found in the parakeets (THRUSFIELD, 2005).

\section{Results}

Ninety-two monk parakeets (35 males, 50 females and 7 unsexed) were collected between August 2006 and April 2007. Among these, 88 birds were bled in the field to obtain blood smears, and 89 underwent necropsies and thorough internal examination of organs in the laboratory.

All 92 individuals caught were examined externally for parasites and 51 (55.4\%; CI 95\%; 45.2-65.6) were found to be parasitized by arthropods (Table 1). Forty-nine (53.3\%; CI 95\%: 43.1-63.5) of the birds presenting parasitic arthropods had the louse Paragoniocotes fulvofasciatum (Insecta: Phthiraptera: Philopteridae; Table 2; Figures 1A, 1B, 1C). One (1.1\%; CI 95\%; -1.0-3.2) of these birds also had a parasitic mite (Arachnida: Acarina: Mesostigmata; Figure 1D). Eight birds (8.7\%; CI 95\%: 2.9-14.5) presented free-ranging mites (Arachnida: Acarina: Oribatida; Figure 1E).

From the 51 monk parakeets that had arthropods, 119 lice, one mesostigmatid mite and 16 oribatid mites were obtained. Among the 49 parasitized birds, the infestation rate ranged from one to nine lice per parakeet, with a mean intensity of 2.43 parasites/parakeet and a mean abundance of 1.29 .

Necropsies and complete examination of internal organs were performed on 89 monk parakeets, which were the individuals in which the digestive organs analyzed were undamaged. Thus, 84 esophagi and crops, 89 stomachs, 88 small intestines and 87 large intestines were included in the endoparasite analyses. No endoparasites were found through direct observation, flotation or sediment examination.

Among the 89 parakeets from which smears were produced using digestive and fecal material, 17 (19.1\%) had acid-alcohol resistant structures of $5 \mu \mathrm{m}$ in diameter that were compatible with Cryptosporidium spp. oocysts (Figure 1F). On the other

Table 1. Frequency of ectoparasites and endoparasites in free-ranging monk parakeets (Myiopsitta monachus) caught in Santiago, Chile.

\begin{tabular}{ccccc}
\hline & Parasite & No. positive (\% positive) & Abundance & No. sampled \\
\hline Ectoparasites & P. fulvofasciatum & $42(45.7)$ & 119 & 92 \\
& Mesostigmatid acari & $1(1.1)$ & 1 & 92 \\
& Free-range acari & $8(8.7)$ & 16 & 92 \\
Total & Ectoparasites & $51(55.4)$ & 136 & 92 \\
Endoparasites & Cryptosporidium & $17(19.1)$ & - & 89 \\
\hline
\end{tabular}

Table 2. Body measurements (in $\mu \mathrm{m}$ ) of Paragoniocotes fulvofasciatum found in $M$. monachus caught in Santiago, Chile.

\begin{tabular}{ccccr}
\hline & & Males $(\mathbf{n}=\mathbf{5 4})$ & Females $(\mathbf{n}=\mathbf{6 2})$ & Nymphs $(\mathbf{n}=\mathbf{3})$ \\
\hline Head & Length & $347.07 \pm 17.32$ & $401.53 \pm 14.01$ & $340 \pm 55.67$ \\
& Width & $302.96 \pm 14.87$ & $328.06 \pm 15.55$ & $283.33 \pm 47.25$ \\
Thorax & Length & $292.41 \pm 19.12$ & $315.96 \pm 14.98$ & $250 \pm 65.57$ \\
& Width & $320 \pm 20.64$ & $347.74 \pm 21.38$ & $280 \pm 62.45$ \\
Abdomen & Length & $805 \pm 85.4$ & $1030.48 \pm 127.63$ & $570 \pm 121.24$ \\
& Width & $368.51 \pm 26.16$ & $404.19 \pm 33.21$ & $326.66 \pm 66.58$ \\
Total length & & $1471.48 \pm 98.55$ & $1747.98 \pm 31.38$ & $1160 \pm 242.48$ \\
\hline
\end{tabular}



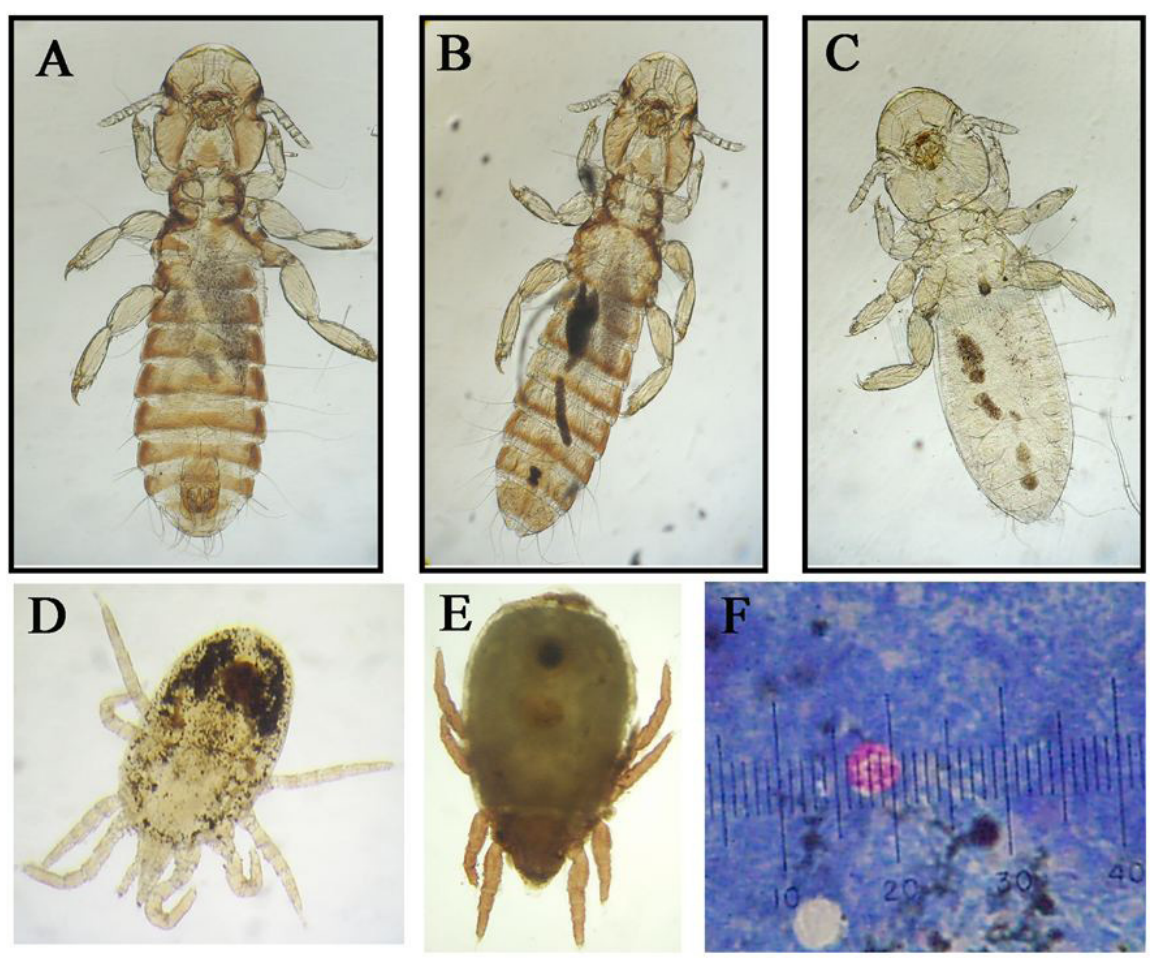

Figure 1. Ectoparasites and endoparasites found in adult monk parakeets (Myiopsitta monachus) caught in Santiago, Chile. The three images (A) to (C) show specimens of Paragoniocotes fulvofasciatum (Insecta: Phthiraptera: Philopteridae): (A) male; (B) female; and (C) nymphal stage. (D) Parasitic acarus belonging to the suborder Mesostigmatida. (E) Free-ranging acarus belonging to the suborder Oribatida. (F) Oocyst of Cryptosporidium spp. detected from fecal material using Ziehl-Neelsen staining. All images were obtained using 10X, except (F), which is at 100X.

hand, no hemoparasites were observed from 88 blood smears stained using Giemsa.

There was no statistically significant association between parasite presence (response variable) and the sex of the parakeets (explanatory variable), as explored using the chi-square test.

\section{Discussion}

In this report, we provide the first description of Paragoniocotes fulvofasciatum in Chile. Although, almost half of the parakeets sampled had this louse, its abundance and intensity per individual was low. This parasite was first described by Picaglia in 1885 in Italy and was found parasitizing a monk parakeet brought to Italy from South America (PALMA, 1973). Guimarães (1947) provided morphometric measurements for a male, and the description of P. fulvofasciatum was completed when Palma (1973), included the description of females from analyses on 91 adults $(39$ males and 52 females) and 125 larvae that were obtained from 16 monk parakeets from the Paraná delta in Argentina, although he did not included morphometric values (see Table 2 ). This parasite would have been introduced with the monk parakeet and, although lice are species specific, they may be a source of transmission of pathogens amongst birds. For instance, helminths have been isolated from bird lice of the suborder Ischnocera, the same suborder to which Paragoniocotes sp. belongs (CLAYTON et al., 2008).

Regarding the single mesostigmatid acarus that was found in one parakeet, it was not possible to determine its species based upon internal structures, since its abdomen was full of content that concealed the structures necessary for identification. This mesostigmatid subfamily, when found in birds or rodents, is often unspecific and zoonotic (BOWMAN, 2014). This may apply to this individual, although further studies including nesting material would provide more individuals for species identification. Regarding the oribatid acari found as a free-ranging subfamily, it is possible that these may have been obtained from the environment, during the short time for which these parakeets remained on the ground prior to collection. It is also possible, that these acari may have been carried from other areas in nesting material brought by the parakeets.

The present study provides the first report of Cryptosporidium spp. in monk parakeets. This protozoon was the only endoparasite found in this study, despite complete analysis of the digestive system and internal organs. Cryptosporidium spp. is a widely distributed zoonotic microorganism that has been used as an environmental sentinel for biotic pollution in wild birds in Chile (FREDES et al., 2007, 2008). Water is a major source of Cryptosporidium spp. contamination and wild birds can contaminate water with oocysts of this protozoon through their droppings. In fact, environmental samples are more likely to be positive for Cryptosporidium spp. when birds are present (JELLISON et al., 2004). Recent evidence has suggested that Cryptosporidium spp. would be more prevalent in intensive dairy production than in more extensive production, probably because of density of hosts (DÍAZ-LEE et al., 2011). In this case, future studies on infection rates due to Cryptosporidium spp. in this species could provide tools 
to pinpoint urban contamination and risk factors associated with this biotic pollutant. Further, it would be important to identify the species of Cryptosporidium found in monk parakeets, as this information will contribute to understanding the epidemiology of the infection. Three species of avian Cryptosporidium spp. have been described: C. meleagridis, C. baileyi and C. galli. From these, C. baileyi is perhaps the most prevalent in birds while C. galli is the most prevalent in passerines. Cryptosporidium meleagridis has been detected in many avian hosts, is a zoonotic species and represents the third most prevalent species of Cryptosporidium in humans (CACCIÒ \& WIDMER, 2014), relevant in case urban citizens are the source of infection. Although $C$. baileyi has been suggested to be zoonotic based upon morphology, size and affinity to organs in chickens inoculated from a human case (DITRICH et al., 1991), this was not confirmed (DITRICH et al., 1993). Thus, future studies in monk parakeets should aim to genetically characterize Cryptosporidium species given that $C$. meleagridis, and perhaps C. baileyi, are two species found in birds which have also been found in humans, representing a zoonotic risk (CACCIÒ \& WIDMER, 2014).

Given that this parakeet is a gregarious species living in dense colonies, it was unexpected to find so few parasites in the parakeets collected, after thorough internal and external examination (CÔTÉ \& POULIN, 1995; EZENWA, 2004; WHITEMAN \& PARKER, 2004; RIFKIN et al., 2012). For instance, no Argas monachus was found. This tick has been associated exclusively with Myiopsitta monachus and all stages of this parasite have been found dwelling in the nests of this parrot (KEIRANS et al., 1973; MASTROPAOLO et al., 2011). One explanation is that this tick is found mainly in nests, rather than attached to adults, which were the sample targeted on the present study. Alternatively, it may be possible that this parasite was not imported along with the parakeet invasion.

The lack of parasitic diversity found in this study could be related to the fact that all birds were obtained from one location. Alternatively, the low parasitic diversity and load obtained in this study may be explained by the "parasitic release hypothesis", in which an invasive species would be less parasitized in a new area, compared with its native populations. Further, this new invasive species would be less parasitized than other similar native species in the area (TORCHIN et al., 2003). One reason for this is that parasites often have complex life cycles that include more than one host, and in the absence of any of these hosts in the new environment, the parasite cycle would be limited. This mechanism may lead to an advantage over native biota (MITCHELL \& POWELL, 2003; TORCHIN et al., 2003), and may have contributed to the demographic explosion observed in populations of this introduced species in Chile. Moreover, parakeets have been observed using certain plants brought daily to nests when breeding. This plant material may act as natural insecticides and bactericides, thus contributing towards reducing biotic hazards and increasing nestling survival and hence their invasive success in new environments (VIANA et al., 2016).

Lastly, considering that monk parakeets are an invasive species that is well adapted to urban environments (i.e. with close proximity to humans and domestic animals), complete surveillance of pathogens in this bird and subsequent risk analyses are warranted for the sake of public health (HULME, 2014). This surveillance should include not only individuals but also their nests.

The present study provides the first description of the presence of Cryptosporidium sp. oocysts in monk parakeets and also the first description of Paragoniocotes fulvofasciatum in Chile.

\section{Acknowledgements}

We would like to thank Patricio Toro for his invaluable assistance in the laboratory and two anonymous reviewers for their constructive recommendations. This work was financed by FIV grant no. 4602006, from the Research Board of the School of Veterinary and Livestock Sciences (FAVET), University of Chile, and initiation grant no. UI009/15 from the Vice-Rectory for Research and Development (VID), University de Chile.

\section{References}

Avery ML, Tillman EA, Keacher KL, Arnett JE, Lundy KJ. Biology of invasive monk parakeets in South Florida. Wilson J Ornithol 2012; 124(3): 581-588. http://dx.doi.org/10.1676/11-188.1.

Blackshaw JK, Fenwick DC, Beattie AW, Allan DJ. The behaviour of chickens, mice and rats during euthanasia with chloroform, carbon dioxide and ether. Lab Anim 1988; 22(1): 67-75. PMid:3127635. http://dx.doi. org/10.1258/002367788780746674.

Bowman D. Georgis' parasitology for veterinarians. 10th ed. Philadelphia: Elsevier Health Sciences, 2014

Brooks TM, Mittermeier RA, Mittermeier CG, Fonseca GAB, Rylands $\mathrm{AB}$, Konstant WR, et al. Habitat loss and extinction in the hotspots of biodiversity. Conserv Biol 2002; 16(4): 909-923. http://dx.doi. org/10.1046/j.1523-1739.2002.00530.x.

Bucher EH, Aramburú RM. Land-use changes and monk parakeet expansion in the pampas grasslands of Argentina. J Biogeogr 2014; 41(6): 1160-1170. http://dx.doi.org/10.1111/jbi.12282.

Burger J, Gochfeld M. Exotic monk parakeets (Myiopsitta monachus) in New Jersey: Nest site selection, rebuilding following removal, and their urban wildlife appeal. Urban Ecosyst 2009; 12(2): 185-196. http://dx.doi. org/10.1007/s11252-009-0094-y.

Bush AO, Lafferty KD, Lotz JM, Shostack AW. Parasitology meets ecology on its own terms: Margolis et al. revisited. J Parasitol 1997; 83(4): 575583. PMid:9267395. http://dx.doi.org/10.2307/3284227.

Cacciò SM, Widmer G. Cryptosporidium: parasite and disease. Wien: Springer-Verlag; 2014.

Clayton DH, Adams RJ, Bush SE. Phthiraptera, the chewing lice. In: Atkinson CT, Thomas NJ, Hunter B, editors. Parasitic diseases of wild birds. Iowa: Wiley-Blackwell; 2008. p. 513-526.

Costa AKF, Sidrim JJC, Cordeiro RA, Brilhante RS, Monteiro AJ, Rocha MF. Urban pigeons (Columba livia) as a potential source of pathogenic yeasts: a focus on antifungal susceptibility of Cryptococcus strains in Northeast Brazil. Mycopathologia 2010; 169(3): 207-213. PMid:19847668. http://dx.doi.org/10.1007/s11046-009-9245-1.

Côté IM, Poulin R. Parasitism and group size in social animals: a metaanalysis. Behav Ecol 1995; 6(2): 159-165. http://dx.doi.org/10.1093/ beheco/6.2.159. 
Daszak P, Cunningham AA, Hyatt AD. Emerging infectious diseases of wildlife-- threats to biodiversity and human health. Science 2000; 287(5452): 443-449. PMid:10642539. http://dx.doi.org/10.1126/ science.287.5452.443.

Díaz-Lee A, Mercado R, Onuoha EO, Ozaki LS, Muñoz P, Muñoz V, et al. Cryptosporidium parvum in diarrheic calves detected by microscopy and identified by immunochromatographic and molecular methods. Vet Parasitol 2011; 176(2-3): 139-144. PMid:21109352. http://dx.doi. org/10.1016/j.vetpar.2010.11.001.

Ditrich O, Kopácek P, Kucerová Z. Antigenic characterization of human isolates of cryptosporidia. Folia Parasitol (Praha) 1993; 40(4): 301-305. PMid:8013932.

Ditrich O, Palkovic L, Sterba J, Prokopic J, Loudová J, Giboda M. The first finding of Cryptosporidium baileyi in man. Parasitol Res 1991; 77(1): 44-47. PMid:1825238. http://dx.doi.org/10.1007/BF00934383.

Domènech J, Carrillo J, Senar JC. Population size of the Monk Parakeet Myiopsitta monachus in Catalonia. Rev Catalana d'Ornitol 2003; 20: 1-9.

Dunn AM, Hatcher MJ. Parasites and biological invasions: parallels, interactions, and control. Trends Parasitol 2015; 31(5): 189-199. PMid:25613560. http://dx.doi.org/10.1016/j.pt.2014.12.003.

Eberhard JR. Breeding biology of the monk parakeet. Wilson Bull 1998; 110(4): 463-473.

Edelaar P, Roques S, Hobson EA, Silva AG, Avery ML, Russello MA, et al. Shared genetic diversity across the global invasive range of the monk parakeet suggests a common restricted geographic origin and the possibility of convergent selection. Mol Ecol 2015; 24(9): 2164-2176. PMid:25873354. http://dx.doi.org/10.1111/mec.13157.

Estrada-Peńa A, Ostfeld RS, Peterson AT, Poulin R, de la Fuente J. Effects of environmental change on zoonotic disease risk: An ecological primer. Trends Parasitol 2014; 30(4): 205-214. PMid:24636356. http://dx.doi. org/10.1016/j.pt.2014.02.003.

Ezenwa VO. Host social behavior and parasitic infection: a multifactorial approach. Behav Ecol 2004; 15(3): 446-454. http://dx.doi.org/10.1093/ beheco/arh028.

Fayer R, Xiao L. Cryptosporidium and cryptosporidiosis. 2nd ed. Boca Raton: Taylor \& Francis Group; 2008.

Fredes F, Díaz A, Raffo E, Muñoz P. Cryptosporidium spp. oocysts detected using acid-fast stain in faeces of gentoo penguins (Pygoscelis papua) in Antarctica. Antarct Sci 2008; 20(5): 495-496. http://dx.doi.org/10.1017/ S0954102008001296.

Fredes F, Raffo E, Muñoz P. First report of Cryptosporidium spp. oocysts in stool of Adélie penguin from the Antarctic using acid-fast stain. Antarct Sci 2007; 19(4): 437-438. http://dx.doi.org/10.1017/S0954102007000429.

Guimarães LR. Contribuiçao ao conhecimento dos malófagos dos psitácidas brasileiros. Arq Zool Est Sao Paulo 1947; 5: 243-309.

Haag-Wackernagel D, Moch H. Health hazards posed by feral pigeons. $J$ Infect 2004; 48(4): 307-313. PMid:15066331. http://dx.doi.org/10.1016/j. jinf.2003.11.001.

Harvell CD, Mitchell CE, Ward JR, Altizer S, Dobson AP, Ostfeld $\mathrm{RS}$, et al. Climate warming and disease risks for terrestrial and marine biota. Science 2002; 296(5576): 2158-2162. PMid:12077394. http:// dx.doi.org/10.1126/science.1063699.
Hulme PE. Invasive species challenge the global response to emerging diseases. Trends Parasitol 2014; 30(6): 267-270. PMid:24862566. http:// dx.doi.org/10.1016/j.pt.2014.03.005.

Invasive Species Specialist Group - ISSG. Myiopsitta monachus (monk parakeet). In: Global Invasive Species Database - GISD. Invasive Species Spec. Gr. IUCN Species Surviv. Comm. [online] 2011 [cited 2015 May 10]. Available from: http://193.206.192.138/gisd/speciesname/ Myiopsitta+monachus

Iriarte AJ, Lobos GA, Jaksic FM. Invasive vertebrate species in Chile and their control and monitoring by governmental agencies. Rev Chil Hist Nat 2005; 78(1): 143-154

Jellison KL, Distel DL, Hemond HF, Schauer DB. Phylogenetic analysis of the hypervariable region of the $18 \mathrm{~S}$ rRNA Gene of Cryptosporidium oocysts in feces of Canada geese (Branta canadensis): evidence for five novel genotypes. Appl Environ Microbiol 2004; 70(1): 452-458. PMid:14711674. http://dx.doi.org/10.1128/AEM.70.1.452-458.2004.

Keesing F, Belden LK, Daszak P, Dobson A, Harvell CD, Holt RD, et al. Impacts of biodiversity on the emergence and transmission of infectious diseases. Nature 2010; 468(7324): 647-652. PMid:21124449. http:// dx.doi.org/10.1038/nature09575.

Keirans JEE, Radovsky FJJ, Clifford CMM. Argas (Argas) monachus, new species (Ixodoidea: Argasidae), from nests of the monk parakeet, Myiopsitta monachus, in Argentina. JMed Entomol 1973; 10(5): 511-516. PMid:4760629. http://dx.doi.org/10.1093/jmedent/10.5.511.

Martin LF, Bucher EH. Natal dispersal and first breeding age in monk parakeets. Auk 1993; 110(4): 930-933. http://dx.doi.org/10.2307/4088651.

Mastropaolo M, Turienzo P, Di Iorio O, Nava S, Venzal JM, Guglielmone AA, et al. Distribution and 16S rDNA sequences of Argas monachus (Acari: Argasidae), a soft tick parasite of Myiopsitta monachus (Aves: Psittacidae) Exp Appl Acarol 2011; 55(3): 283-291. PMid:21739257. http://dx.doi. org/10.1007/s10493-011-9469-x.

Mitchell MS, Powell RA. Response of black bears to forest management in the southern appalachian mountains. J Wildl Manage 2003; 67(4): 692-705. http://dx.doi.org/10.2307/3802676.

Myers N, Mittermeier RA, Mittermeier CG, Fonseca GA, Kent J. Biodiversity hotspots for conservation priorities. Nature 2000; 403(6772): 853-858. PMid:10706275. http://dx.doi.org/10.1038/35002501.

Navarro JL, Martella MB, Bucher EH. Effects of laying date, clutch size, and communal nest size on the reproductive success of monk parakeets. Wilson Bull 1995; 107(4): 742-746.

Palma RL. On some Mallophaga parasite on Argentine birds. Physis Sección C 1973; 32(85): 483-498.

Palma RL. Slid-mounting of lice: a detailed description of the Canada balsam technique. NZ Entomol 1978; 6(4): 432-436. http://dx.doi.org /10.1080/00779962.1978.9722313.

Price RD, Hellenthal RA, Palma RL, Johnson KP, Clayton DH. The chewing lice: world checklist and biological overview. Springfield: Illinois Natural History Survey Special Publication; 2003.

Reed JE, McCleery RA, Silvy NJ, Smeins FE, Brightsmith DJ. Monk parakeet nest-site selection of electric utility structures in Texas. Landsc Urban Plan 2014; 129: 65-72. http://dx.doi.org/10.1016/j. landurbplan.2014.04.016.

Rifkin JL, Nunn CL, Garamszegi LZ. Do Animals Living in Larger Groups Experience Greater Parasitism? A Meta-Analysis. Am Nat 2012; 180(1): 70-82. PMid:22673652. http://dx.doi.org/10.1086/666081. 
Rodríguez-Pastor R, Senar JC, Ortega A, Faus J, Uribe F, Montalvo T. Distribution patterns of invasive Monk parakeets (Myiopsitta monachus) in an urban habitat. Anim Biodivers Conserv 2012; 35(1): 107-117.

Smith KF, Acevedo-Whitehouse K, Pedersen AB. The role of infectious diseases in biological conservation. Anim Conserv 2009; 12(1): 1-12. http://dx.doi.org/10.1111/j.1469-1795.2008.00228.x.

Soulsby EJL. Parasitología y enfermedades parasitarias en los animales domésticos. 7 ed. México: Nueva Ed. Interamericana; 1987.

Tala C, Guzmán P, González S. Cotorra argentina (Myiopsitta monachus) convidado de piedra en nuestras ciudades y un invasor potencial, aunque real, de sectores agricolas. Santiago: Servicio Agrícola y Ganadero - División de Protección de los Recursos Naturales Renovables; 2005. Boletín DIPROREN.

Thompson RCA. Parasite zoonoses and wildlife: one health, spillover and human activity. Int J Parasitol 2013; 43(12013): 1079-1088. PMid:23892130. http://dx.doi.org/10.1016/j.ijpara.2013.06.007.
Thrusfield M. Veterinary epidemiology. 3rd ed. Oxford: Blackwell Publishing; 2005.

Torchin ME, Lafferty KD, Dobson AP, McKenzie VJ, Kuris AM. Introduced species and their missing parasites. Nature 2003; 421(6923): 628-630. PMid:12571595. http://dx.doi.org/10.1038/nature01346.

Van Ham C, Genovesi P, Scalera R. Invasive alien species: the urban dimension - case studies on strengthening local action in Europe. Brussels, Belgium: IUCN European Union Representative Office; 2013

Viana IR, Strubbe D, Zocche JJ. Monk parakeet invasion success: a role for nest thermoregulation and bactericidal potential of plant nest material? Biol Invasions 2016; 18(5): 1305-1315. http://dx.doi.org/10.1007/ s10530-016-1068-7.

Whiteman NK, Parker PG. Effects of host sociality on ectoparasite population biology. J Parasitol 2004; 90(5): 939-947. http://dx.doi. org/10.1645/GE-310R. 